\title{
Jerzy Janczewski
}

Akademia Humanistyczno-Ekonomiczna w Łodzi

\section{Doskonalenie zawodowe kierowców a przedsiębiorczość}

Branża transportowa, z uwagi na swą specyfikę, w sposób szczególny wymaga kształtowania kompetencji ${ }^{1}$ pracowników - zwłaszcza kierowców, którzy mają zasadniczy wpływ na bezpieczeństwo ruchu drogowego, stan taboru oraz związane z nim koszty eksploatacji. To od stylu i techniki jazdy kierowcy zależy bezpośrednio, czy ładunek dotrze bezpiecznie do miejsca przeznaczenia, a pośrednio - liczba usterek wyłączających pojazd z ruchu drogowego.

Szkolenie zawodowe pracowników, które przejawia się najpierw w dobrym przygotowaniu do zawodu, potem zaś w ciągłym kształtowaniu umiejętności i nabywaniu nowej wiedzy, stanowi podstawę przedsiębiorczego zarządzania firmą. Odpowiednio wykwalifikowani pracownicy - w głównej mierze wykwalifikowani i odpowiednio wyszkoleni kierowcy - to jeden z najważniejszych czynników mających wpływ na funkcjonowanie firm. Kierowcy powinni ciągle doskonalić się zawodowo i kształtować swoje umiejętności z zakresu techniki i bezpieczeństwa jazdy oraz eksploatacji pojazdu, a szkolenia - zarówno te obligatoryjne, jak i dodatkowe - powinny mieć na celu umożliwienie i ułatwienie tego doskonalenia. Jednym z szybkich rezultatów szkoleń dodatkowych (nieobligatoryjnych) jest między innymi zmniejszenie zużycia paliwa nawet o $10 \% \mathrm{w}$ pojazdach prowadzonych przez tych samych kierowców po szkoleniu. Oczywiste jest jednak, że nie tylko umiejętności wpływają na efektywność pracownika, równie ważna jest wiedza - zarówno ta specjalistyczna, związana z wykonywanym zawodem, jak i ogólna, pozwalająca lepiej zrozumieć uwarunkowania sytuacyjne (Uniwersalny model kompetencyjny 2011). Czynnikiem o podstawowym znaczeniu jest także przedsiębiorcza postawa pracownika, która określa to, w jakim stopniu pracownik wykorzystuje i rozwija umiejętności oraz swoją wiedzę. Można więc z pewnym przybliżeniem założyć, że jakość zawodowych działań pracowników determinują między innymi kompetencje oraz przedsiębiorcze postawy.

Celem niniejszej publikacji jest analiza systemu szkolenia kierowców zawodowych z punktu widzenia racjonalnej eksploatacji samochodu i bezpieczeństwa ruchu drogowego, ze wskazaniem szkoleń obligatoryjnych i nieobligatoryjnych i z uwzględnieniem roli przedsiębiorczości jako nieodzownej cechy mobilnego personelu przedsiębiorstwa transportowego.

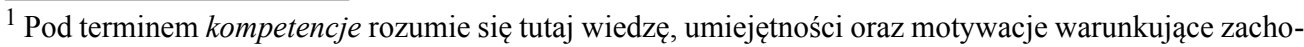
wania, które umożliwiają realizację zadań zawodowych zgodnie z oczekiwaniami.
} 


\section{Zawód kierowca}

Zawód kierowca ${ }^{2}$ obejmuje dwie grupy zawodowe. Do pierwszej z nich należą kierowcy samochodów osobowych, dostawczych i motocykli (w tym kierowcy taksówek), a do drugiejkierowcy ciężarówek i autobusów (w tym kierowcy trolejbusów, motorniczowie tramwajów, kierowcy autocystern, ciągników siodłowych i samochodów ciężarowych). Kierowca należy do kategorii zawodów trudnych i niebezpiecznych, czyli tych, gdzie praca związana jest z narażeniem życia i (lub) zdrowia osoby ją wykonującej i z zagrożeniem dla innych ludzi. W przypadku zawodu kierowcy zagrożenie dla życia lub zdrowia wynika z wysokiego poziomu obciążenia psychicznego podczas prowadzenia pojazdu, konieczności obsługi pojazdu oraz warunków środowiska pracy (Łuczak, Najmiec 2009).

W Polsce brak jest szczegółowych danych na temat liczby kierowców zawodowych wykonujących przewozy osób i przewozy towarowe - łączne zatrudnienie kierowców zawodowych można szacować ${ }^{3}$ obecnie na około 800 tysięcy osób.

Kierowcy autobusów, trolejbusów i motorniczowie tramwajów to przede wszystkim kierowcy komunikacji miejskiej lub dalekobieżnej, świadczący usługi o charakterze masowym, polegające na przewozie pasażerów. W przypadku komunikacji miejskiej przewóz realizowany jest w obrębie miasta lub metropolii i odbywa się na krótkich odcinkach z dużą liczbą przystanków, natomiast w przypadku komunikacji dalekobieżnej przewóz osób realizowany jest na długich odcinkach. Kierowcy taksówek również realizują przewozy pasażerów, lecz na mniejszą skalę w porównaniu z kierowcami autobusów, a ich usługi mają charakter bardziej indywidualny i są dokonywane na życzenie klienta. Do obowiązków kierowcy, poza prowadzeniem autobusu, tramwaju czy taksówki, należy sprawdzenie stanu technicznego pojazdu i przygotowanie go do jazdy. Kierowca komunikacji miejskiej i dalekobieżnej jeździ określoną trasą, zatrzymuje się na przystankach, otwiera i zamyka drzwi, wpuszcza i wypuszcza pasażerów. W pracy kierowcy występują rutynowo powtarzane czynności, wymagające ciągłej obserwacji sytuacji na drodze i koncentracji na wszystkich jej elementach, tj. ruchu innych pojazdów, zachowaniu pieszych, znakach drogowych, zmianie świateł sygnalizacyjnych, a także obserwacji pracy własnego pojazdu i dostosowaniu stylu jazdy do panujących na drodze warunków. Dodatkowym czynnikiem jest czas, gdyż kierowca autobusu, trolejbusu i motorniczy tramwaju zobowiązany jest do przestrzegania rozkładu jazdy: na kolejne przystanki powinien przyjeżdżać punktualnie o wyznaczonej porze, co w zatłoczonych miastach, zwłaszcza w godzinach szczytu, jest trudne do realizacji. Kierowcy komunikacji miejskiej odpowiedzialni są za bezpieczeństwo przewożonych pasażerów oraz za powierzony im środek transportu.

Kierowca transportu towarowego zajmuje się przewozem towarów. Po otrzymaniu zlecenia jedzie do wyznaczonego miejsca, gdzie zabiera towar i zawozi go w umówione miejsce (np. do sklepu, firmy). Do zadań na tym stanowisku należy też zazwyczaj załadunek i rozładunek towarów, a w przypadku kierowcy jeżdżącego na trasach międzynarodowych także załatwianie formalności celnych. Praca na tym stanowisku związana jest z częstym przebywaniem poza domem, zazwyczaj długimi postojami na przejściach granicznych oraz monotonią długich tras (Łuczak, Najmiec 2009).

\footnotetext{
${ }^{2}$ Rozporzadzenie Ministra Pracy i Polityki Spolecznej z dnia 27 kwietnia 2010 r. w sprawie klasyfikacji zawodów i specjalności na potrzeby rynku pracy oraz zakresu jej stosowania (Dz.U. z $2010 \mathrm{Nr} 83$, poz. 537 , kod 832 i 833 ).

${ }^{3}$ Łączne zatrudnienie kierowców zawodowych oszacowano na podstawie Mitraszewska, Kamińska 2007, s. $4-16$.
} 
Kolejną grupą kierowców są kierowcy flotowi, którzy ze względu na istotny udział czynności związanych z prowadzeniem pojazdu w zakresie swoich obowiązków służbowych traktowani są jako szczególna grupa kierowców zawodowych (Łuczak, Najmiec 2009). Praca kierowcy flotowego polega na częstych wyjazdach samochodem służbowym, zarówno na trasach długich (w różne miejsca kraju), jak i krótkich (w obrębie jednego miasta), w ramach wykonywania swoich obowiązków służbowych, do których należą na przykład kontaktowanie się z klientami, reklamowanie i sprzedawanie określonych produktów firmy. Wyjazdy odbywają się w różnych porach dnia, czasem trwają kilka dni. Kierowca flotowy jeździ samodzielnie albo w towarzystwie współpracowników. Szczególnym zagrożeniem w pracy kierowcy flotowego jest ryzyko wypadku drogowego, które dla firmy skutkuje wyższymi kosztami ubezpieczeń i czasowym wyłączeniem pojazdu z ruchu. Ryzyko wypadku jest szczególnie duże ze względu na stres wynikający z charakteru pracy kierowcy flotowego, gdzie podstawową trudnością jest konieczność częstego i szybkiego przerzucania się z głównych zadań zawodowych na czynności związane z prowadzeniem samochodu. Te pierwsze, jeśli są związane z kontaktem z klientami, mogą stanowić potencjalne źródło konfliktów i dodatkowego stresu. Dlatego ważne jest, aby kierowca flotowy posiadał umiejętność oddzielenia tych etapów pracy i nieprzenoszenia emocji na drogę. Kierowca flotowy pracuje zazwyczaj pod presją czasu. Niejednokrotnie podczas prowadzenia pojazdu rozmawia przez telefon komórkowy, co nawet przy zastosowaniu obowiązujących zestawów głośnomówiących powoduje, że uwaga jest rozproszona i zależna od umiejętności jej podzielności i znaczenia emocjonalnego przypisywanego treści rozmowy. Często także w czasie krótkich postojów na światłach kierowca flotowy próbuje pracować z laptopem lub ustawia system nawigacji pojazdu (Łuczak, Najmiec 2009).

W polskich szkołach zawodowych już od dawna nie kształci się kierowców samochodów ciężarowych i autobusów, coraz rzadziej wymaga się też od kierowców znajomości pojazdu od strony technicznej. Coraz więcej firm transportowych posiada umowy ubezpieczeniowe zawierające assistance, co oznacza, że w przypadku jakichkolwiek problemów technicznych w trasie kierowca nie ma prawa samodzielnie dokonywać naprawy, ale powinien zawiadomić o tym centralę assistance, która usunie usterkę. Z tego powodu programy szkoleń kierowców nie kładą szczególnego nacisku na zagadnienia techniczne, a uwypuklają zagadnienia bezpieczeństwa i organizacji przewozu. Kierowca musi znać zasady funkcjonowania podstawowych elementów i zespołów samochodu, ale nie po to, by je naprawiać, lecz by wiedzieć, jak z nich korzystać, aby jeździć ekonomicznie i ekologicznie, i unikać sytuacji, które mogą narazić pracodawcę na niepotrzebne koszty (Czy zabraknie kierowców zawodowych?).

\section{System szkolenia kierowców}

Kierowca w trakcie szkoleń powinien nabywać wiedzę i umiejętności w zakresie znajomości właściwości technicznych i zasad działania elementów bezpieczeństwa pojazdu, optymalizacji zużycia paliwa, zapewnienia bezpieczeństwa w związku z przewożonym towarem, zapewnienia bezpieczeństwa pasażerom, stosowania przepisów dotyczących wykonywania transportu drogowego, zapobiegania zagrożeniom związanym z wykonywanym zawodem, w tym bezpieczeństwo na drodze i bezpieczeństwo środowiska, umiejętności w zakresie prawidłowej obsługi i logistyki, w tym kształtowanie wizerunku firmy oraz znajomość rynku w przewozie drogowym i organizacji przewozu. Dla osiągnięcia tych celów stworzono system szkolenia kierowców, którego podstawą są uregulowania prawne o ruchu i transporcie drogowym, określające zasady uzyskiwania uprawnień do kierowania pojazdami i wykonywania zawodu kierowcy. 
Zgodnie z definicją, system jest obiektem, w którym można wyróżnić powiązane ze sobą kolejne elementy. Oprócz uregulowań prawnych system szkolenia kierowców obejmuje zatem wielu uczestników, od kandydatów na kursy na prawo jazdy, poprzez autoszkoły i instytucje, które odpowiadają za realizację szkolenia, po placówki służby zdrowia (ryc. 1.) Jako uczestników systemu szkolenia należy również wymienić firmy oferujące szeroki wachlarz kursów i szkoleń dokształcających kierowców w zakresie bezpieczeństwa jazdy, eco-drivingu, jazdy defensywnej itp. Osoby, które ubiegają się o uzyskanie prawa jazdy, w pierwszej kolejności przechodzą badania lekarskie i testy psychologiczne, mające wykazać ewentualne przeciwwskazania w uzyskaniu uprawnień. Nadzór nad lekarzami i psychologami posiadającymi specjalne kwalifikacje prowadzi wojewoda, zaś wymagania, które muszą spełniać, określa ustawodawca. Osoby, u których nie wykryto przeciwwskazań do kierowania pojazdem, mogą uczestniczyć w kursie nauki jazdy w wybranym przez siebie ośrodku szkolenia kierowców (OSK). Na tym etapie bardzo istotnym elementem systemu szkolenia kierowców jest instruktor, od którego kwalifikacji i podejścia w dużej mierze zależy efekt końcowy - w postaci zdanego egzaminu państwowego. Po odbytym szkoleniu kursanci przystępują do egzaminu państwowego na prawo jazdy w wojewódzkim ośrodku ruchu drogowego (WORD), gdzie egzaminatorzy sprawdzają nabyte w trakcie kursu umiejętności. Nadzór nad WORD-em ma urząd marszałkowski. Osoby, które uzyskuje prawo jazdy, mogą dalej doskonalić swoje umiejętności, na przykład w ośrodkach doskonalenia techniki jazdy.

Ryc. 1. Uczestnicy systemu szkolenia kierowców w Polsce

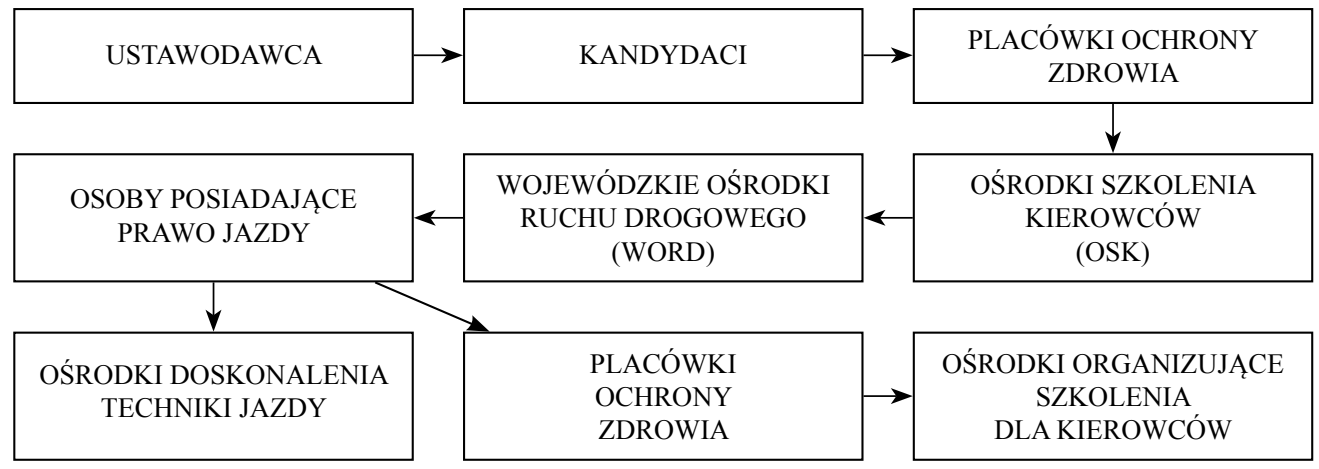

Źródło: opracowanie własne autora na podstawie Ustawy z dnia 20 czerwca 1997 r. Prawo o ruchu drogowym ze zmianami, które weszły w życie do dnia 6 maja 2011 r.

Osoby, które decydują się na wykonywanie zawodu kierowcy, muszą przejść szereg kolejnych szkoleń (ryc. 2), w tym badania lekarskie i psychotesty czy kwalifikację wstępną w przypadku kategorii C, C+E - przewóz rzeczy - lub kategorii D - przewóz osób. Nadzór nad dodatkowymi szkoleniami dla kierowców prowadzi wojewoda. W celu zapewnienia stałego podnoszenia jakości szkolenia wprowadzono nadzór merytoryczny nad OSK, a w ostatnich czasach zweryfikowano to pojęcie na system doradztwa. 
Ryc. 2. Proces szkolenia kierowców w Polsce

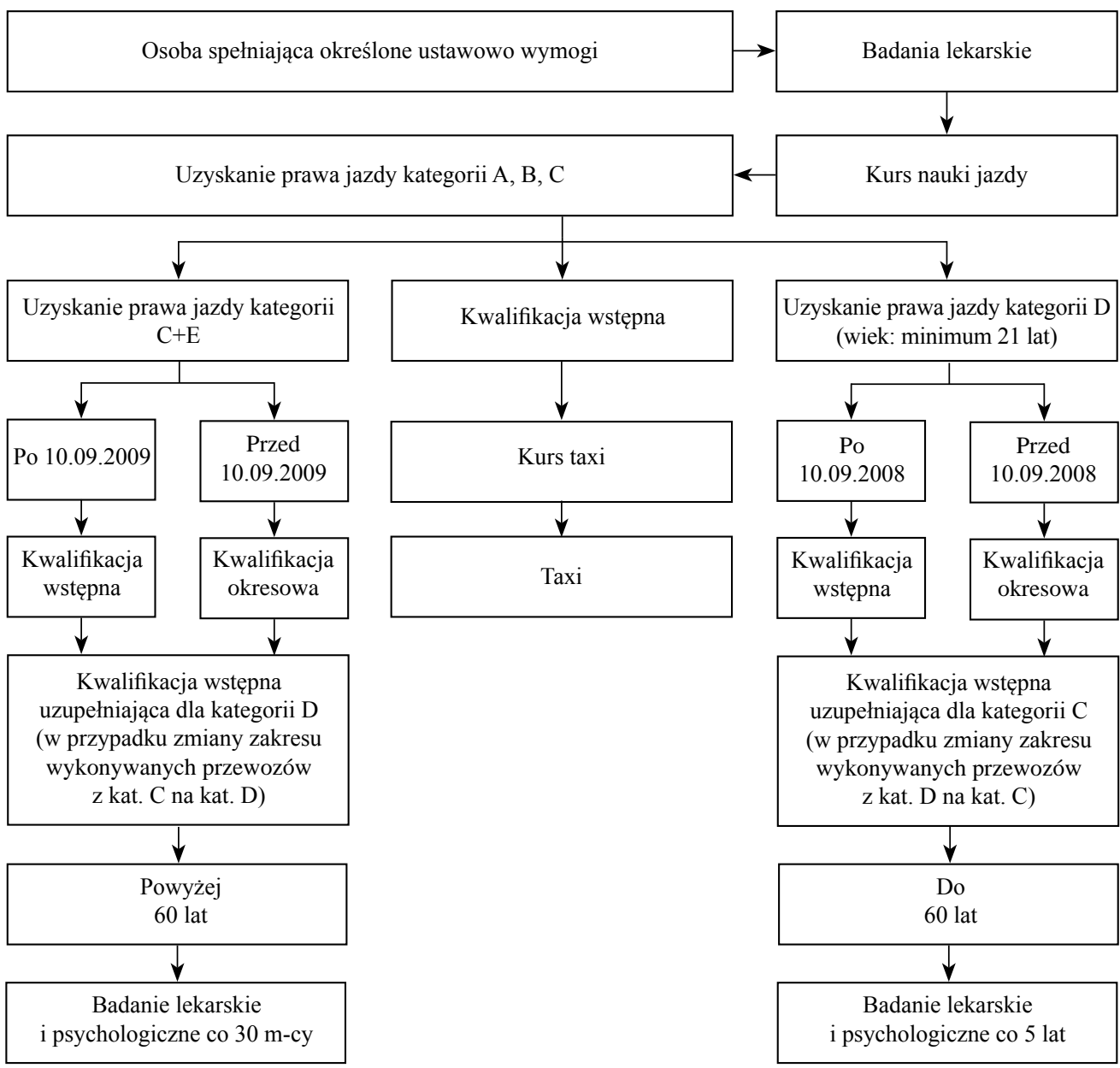

Źródło: opracowanie własne autora na podstawie Ustawy z dnia 20 czerwca 1997 r. Prawo o ruchu drogowym ze zmianami, które weszły w życie do dnia 6 maja 2011 r. i Ustawy z dnia 6 września 2001 r. o transporcie drogowym ze zmianami, które weszły w życie do dnia 1 września 2011 r.

Szkolenia osób umożliwiające zdobycie uprawnień do kierowania pojazdami i w konsekwencji umożliwiające pracę w zawodzie kierowcy w Polsce można przedstawić także w formie trzech modułów uwzględniających kolejne etapy uzyskiwania uprawnień do kierowania i kwalifikacji zawodowych - obrazuje to tabela 1. Natomiast w tabeli 2 przedstawiono szkolenia dla kierowców zawodowych w Polsce, przy czym do szkoleń obligatoryjnych zaliczono kwalifikację wstępną, okresową i uzupełniającą ${ }^{4}$, a jako przykłady, spośród wielu oferowanych na rynku, wybrano szkolenia nieobligatoryjne.

\footnotetext{
${ }^{4}$ Jako ciekawostkę można podać, że w Polsce nie ma sankcji za brak zdanego egzaminu kwalifikacyjnego u kierowcy zawodowego. Jeżeli policjant lub inspektor transportu drogowego zauważy w prawie jazdy kierowcy brak wpisu potwierdzającego zdanie egzaminu kwalifikacyjnego, może kierowcę jedynie pouczyć (Czy zabraknie kierowców zawodowych?).
} 
Tab. 1. Moduły szkoleń umożliwiające zdobycie uprawnień do kierowania pojazdami i pracę w zawodzie kierowcy

\begin{tabular}{|c|l|}
\hline \multirow{3}{*}{ Moduł 0 } & $\begin{array}{l}\text { Uzyskanie następujących uprawnień: } \\
- \text { karta rowerowa, } \\
- \text { prawo jazdy kategorii A, } \\
- \text { prawo jazdy kategorii B, B+E }\end{array}$ \\
\hline Moduł I & $\begin{array}{l}\text { Uzyskanie następujących uprawnień: } \\
- \text { prawo jazdy kategorii C } \\
- \text { prawo jazdy kategorii C+E } \\
- \text { prawo jazdy kategorii D }\end{array}$ \\
\hline Moduł II & $\begin{array}{l}\text { Wszelkie szkolenia umożliwiające wykonywanie zawodu kierowcy } \\
\text { (zarówno obligatoryjne - kwalifikacje - jak i nieobligatoryjne }- \\
\text { np. dodatkowe szkolenie z zakresu doskonalenia techniki jazdy) }\end{array}$ \\
\hline
\end{tabular}

Źródło: opracowanie własne autora.

Tab. 2. Szkolenia kierowców zawodowych w Polsce

\begin{tabular}{|c|c|}
\hline SZKOLENIA OBLIGATORYJNE & $\begin{array}{c}\text { SZKOLENIA NIEOBLIGATORYJNE } \\
\text { (przyklady) }\end{array}$ \\
\hline \multirow[b]{2}{*}{ kwalifikacja wstępna } & doskonalenie techniki jazdy \\
\hline & $\begin{array}{l}\text { program szkolenia i samokształcenia kierowców } \\
\text { ERIC }\end{array}$ \\
\hline \multirow[t]{2}{*}{ kwalifikacja okresowa } & $\begin{array}{l}\text { program doskonalenia techniki jazdy - Scania } \\
\text { Driver Support }\end{array}$ \\
\hline & program Bezpieczne Auto Firmowe (Fleet Safety) \\
\hline \multirow{3}{*}{ kwalifikacja uzupełniająca } & szkolenia ekojazdy (ECO-Driving) \\
\hline & szkolenia EVO-BUS Polska \\
\hline & szkolenie z ryzyka w ruchu drogowym \\
\hline
\end{tabular}

Źródło: opracowanie własne autora

\section{Szkolenia nieobligatoryjne}

Szkolenia nieobligatoryjne są szkoleniami dobrowolnymi, prowadzonymi przez różne organizacje, między innymi przez producentów samochodów, prowadzących teoretyczne i praktyczne zajęcia dla kierowców. Wśród najczęściej stosowanych sposobów edukacji kierowców najczęściej wymienia się: audyty bezpieczeństwa dla flot samochodowych, szkolenia teoretyczne prowadzone przez policję drogową, ratowników medycznych, psychologów, szkolenia jazdy defensywnej, szkolenia ekokierowcy, szkolenia bezpiecznych zachowań w sytuacjach ekstremalnych, szkolenia na symulatorach jazdy i szkolenia specjalistyczne (Fleet Conference 2010).

Na uwagę zasługuje też fakt, iż większość kierowców doświadczyło już jakiejś formy agresji ze strony innych użytkowników drogi, stąd w procesie treningowym kierowców stosuje się różne rodzaje testów psychologicznych, np. testy temperamentalno-osobowościowe, testy diagnostyczne deficytów i predyspozycji dla kierowców, testy skłonności do zachowań agresywnych oraz testy narzędziowe wykonywane w warsztatach zachowań. Testy te przynoszą liczne korzyści zarówno dla pracodawcy, jak i dla kierowców oraz procesu szkoleniowego 
(umożliwiają rozpoznanie potrzeb szkoleniowych grupy, ułatwiają określenie konstrukcji szkolenia oraz pomagają w dobraniu odpowiedniego trenera dla konkretnych osób).

Jednym ze szkoleń nieobligatoryjnych jest szkolenie z zakresu doskonalenia techniki jazdy, w którym zasadniczą rolę odgrywają właściwie dobrane ćwiczenia praktyczne, gdzie każdy kierowca zawsze jest traktowany indywidualnie. Szkolenie rozpoczyna się od eliminacji podstawowych błędów, a następnie kolejno wprowadza się nowe, trudniejsze elementy. Rola instruktorów polega przede wszystkim na stwarzaniu trudnych, niecodziennych sytuacji, z którymi kierowcy nie spotykają się często na drogach. Sytuacje takie można bez narażenia życia i zdrowia imitować na symulatorach jazdy, pozwalając kierowcom popełniać błędy i doświadczać uczucia bezsilności wobec praw fizyki i prowokując przez to zachowania intuicyjne, które nieuchronnie prowadzą do utraty kontroli nad pojazdem. Ten etap szkolenia jest istotny dla kształtowania świadomości zagrożeń i odpowiedniej postawy kierującego, gdyż kilkakrotne przeżycie niepowodzenia za kierownicą uświadamia kierowcy, że nie jest on przygotowany na trudne sytuacje drogowe i że może stać się sprawcą wypadku. Kiedy kierowca już zmierzy się z nowym wyzwaniem, sprawdzi i oceni swoje umiejętności, zdiagnozuje popełniane błędy, rozpoczyna się u niego żmudny proces ich eliminowania. Słusznie zakłada się tutaj, że świadomy kierowca będzie chciał już stale doskonalić swoje kompetencje, uczyć się właściwych reakcji i zachowań, aby czuć się na drodze bezpieczniej.

W ostatnich latach coraz więcej uwagi poświęca się szkoleniom mającym na celu zwiększenie bezpieczeństwa ruchu drogowego oraz korzyści eksploatacyjnych dla firm transportowych. Pojawia się tym samym coraz więcej ofert szkoleń nieobligatoryjnych doskonalących techniki jazdy i ogólnie zwiększających zasoby posiadanej już przez kierowców wiedzy, niekiedy też wiedza ta jest z różnych powodów przypomniana i powtarzana. Przykładem takiego szkolenia może być szkolenie ERIC opracowane w Instytucie Transportu Samochodowego w ramach międzynarodowego projektu badawczego ERIC (Experiencing CBT Programmes In Road Safety In the European Community). Jest to projekt edukacyjny dotyczący szkolenia i samokształcenia kierowców. Jego głównymi elementami są testy sprawdzające wpływ długości i monotonii jazdy na kierowcę i jego możliwości percepcji oraz symulacja oceny odległości od poprzedzającego pojazdu w różnych warunkach atmosferycznych i o różnej porze doby. Osoby biorące udział w takim szkoleniu poznają także czynniki powstawania zmęczenia, jego wpływ na wydolność organizmu, a także sposoby radzenia sobie ze zmęczeniem i stresem. Projekt ERIC obejmuje również interaktywny zestaw zadań przypominający podstawy fizyki jazdy (ERIC przeszkoli kierowców).

Szkolenia nieobligatoryjne są też organizowane przez producentów określonych marek pojazdów. I tak dla przykładu w marcu 2009 roku Mercedes-Benz zorganizował po raz kolejny dwudniowe szkolenia dla kierowców autokarów. W pierwszym dniu kursanci poznawali temat bezpieczeństwa, natomiast drugi dzień poświęcony był ekonomice jazdy (Mercedes szkoli kierowców). Dla odmiany producent samochodów ciężarowych Scania opracował program Scania Driver Support, który nie wymaga poświęcania dodatkowego czasu na szkolenie. Ten stosunkowo nowatorski system wsparcia pomaga w samodoskonaleniu i utrwaleniu przez kierowców wcześniej nabytych umiejętności, na przykład w trakcie szkolenia obligatoryjnego, i w przyszłości ma być standardowo dostępny w większości długodystansowych pojazdów Scania. Działanie systemu koncentruje się na elementach, które mają istotny wpływ na bezpieczeństwo i oszczędność paliwa. System analizuje zasadnicze parametry kierowania pojazdem, na bieżąco udziela kierowcy wskazówek, a po zakończonej jeździe generuje podsumowanie z oceną stylu jazdy. System Scania Driver Support ma za zadanie motywować kierowcę do doskonalenia stylu jazdy, uświadamiając mu jednocześnie popełniane błędy i wskazując 
potencjalne możliwości poprawy. Pomagając w nauce bezpiecznego i efektywnego kierowania pojazdem, jednocześnie nie rozprasza uwagi kierowcy czy też nie irytuje go. W celu opracowania odpowiednich parametrów i metod porównawczych Scania zgromadziła i przeanalizowała dużą liczbę danych eksploatacyjnych zebranych z różnych okresów i w czasie realizacji tych samych zadań transportowych. Zarówno przed, jak i po zainstalowaniu systemu Scania Driver Support, mierzono zużycie paliwa u różnych kierowców i okazało się, iż kierowcy korzystający z systemu są w stanie natychmiast zredukować zużycie paliwa nawet o 10\%. Kierowcy, którzy uczestniczyli w opracowywaniu i testach eksploatacyjnych Scania Driver Suport, wysoko ocenili przydatność systemu do utrwalania i doskonalenia swoich umiejętności (Scania Driver Support). Podobne rozwiązanie, które jest wsparciem dla kierowcy i wysyła do niego na bieżąco zwrotne informacje o naruszeniach preferowanego stylu jazdy, pomagając w kształtowaniu nawyków jazdy bezpiecznej i ekonomicznej, wdrożono w części autobusów komunikacji miejskiej w Gdańsku (Autobusy komunikacji miejskiej). W skali całej firmy transportowej oszczędności wygenerowane na zużytym paliwie, a także kosztach eksploatacyjnych samochodu sięgające nawet do kilku procent są zadawalające zwłaszcza przy stale rosnących cenach paliwa.

Oprócz ciągłych szkoleń i kursów dla kierowców samochodów ciężarowych i autobusów istotne jest również stałe monitorowanie szkodowości oraz szkolenia kierowców flotowych. Okazuje się, że przynosi to wymierne efekty, ponieważ redukcja kosztów utrzymania floty samochodów firmowych wygenerowana dzięki efektywniejszemu używaniu samochodów, zmniejszeniu liczby wypadków oraz wyższym wartościom rezydualnym stanowi korzyść dla organizacji, nawet jeśli jest ujmowana w ewidencji jako oszczędność kosztów (Cooke 2004). Przykładem może być firma Cadbury Wedel, która od dwóch lat realizuje nowatorski program bezpiecznej floty: „Fleet Safety - bezpieczne auto firmowe”. Program ten prowadzony jest przez PZU, we współpracy z Polskim Stowarzyszeniem Motorowym i wydawnictwem IPM. Głównym celem prowadzonych w jego ramach szkoleń jest prewencja i podnoszenie wiedzy, świadomości i umiejętności kierowców samochodów firmowych, a przede wszystkim zwiększenie bezpieczeństwa kierowców i pozostałych użytkowników dróg i - co za tym idzie znaczne oszczędności eksploatacyjne (Bezpiecznie znaczy oszczędnie).

Innym przykładem są szkolenia oferowane przez Szkołę Bezpiecznej Jazdy Carefleet z Warszawy, których celem jest zmniejszenie wypadkowości i zwiększenie bezpieczeństwa w polskich flotach oraz nauka jazdy w taki sposób, aby pojazd zużywał jak najmniej paliwa. Zajęcia obejmują elementy teoretyczne i praktyczne. W czasie szkolenia teoretycznego uczestnicy poznają podstawowe zagadnienia bezpiecznego prowadzenia pojazdu, zachowanie samochodu na różnych nawierzchniach, zasadę działania układów bezpieczeństwa czynnego, sztukę przewidywania, trudne manewry na drodze i przyczyny wypadków oraz sposoby ich unikania, a także zapoznają się z czynnikami powodującymi nadmierne zużycie paliwa. Szkolenie praktyczne obejmuje takie zagadnienia, jak: nauka hamowania z systemem ABS, hamowanie przed przeszkodą i bezpieczne omijanie przeszkody, nauka pokonywania zakrętów, ciasnych łuków i nawrotów, posługiwanie się ręcznym hamulcem, hamowanie progresywne $\mathrm{z}$ dużych prędkości, sztuka zachowania w trudnych sytuacjach, nauka płynnego prowadzenia samochodu z właściwą zmianą biegów, nauka hamowania silnikiem, planowania i przewidywania trasy jazdy (Fleet \& Business Day 2010). 


\section{Sondaż wśród kierowców zawodowych i instruktorów nauki jazdy na temat potrzeby szkoleń}

Kwalifikacja wstępna, okresowa, uzupełniająca oraz szkolenia nieobowiązkowe mają co prawda na celu ciągłe doskonalenie kompetencji kierowców, również tych z dłuższym stażem pracy, ale nie wszyscy wykonujący ten zawód odnoszą się pozytywnie do potrzeby szkoleń. Zdania kierowców są podzielone, o czym może świadczyć sondażowe badanie niektórych kierowców, zatrudnionych w firmach transportowych ${ }^{5}$.

Można przypuszczać, iż opinia o szkoleniach zależy w dużej mierze od wieku kierowcy, stażu zawodowego oraz doświadczenia, co przykładowo pokazano w tabeli 3 . Należy podkreślić, że przeprowadzone badanie jest tylko sondażem i nie jest reprezentatywne z uwagi na małą liczbę badanych kierowców. Podobny sondaż o potrzebie szkoleń kierowców przeprowadzono także wśród kilku instruktorów nauki jazdy, którzy przeciwnie do kierowców zawodowych wyrazili zgodną opinię, iż szkolenia kierowców prowadzone w każdej postaci są konieczne, gdyż przyczyniają się do wzrostu bezpieczeństwa wszystkich uczestników ruchu drogowego. Dla poparcia swojej tezy instruktorzy wskazali na przykłady nieracjonalnego prowadzenia pojazdów przez kierowców zawodowych - zwłaszcza samochodów ciężarowych. Z uwagi na charakter pracy, instruktorzy posiadają bieżący kontakt ze wszystkimi uczestnikami ruchu i obserwują przypadki zachowań rutynowych wśród kierowców zawodowych oraz brak kultury jazdy, przejawiający się między innymi eksponowaniem braku tolerancji w stosunku do kandydatów na kierowców. Nie bez powodu Prawo o ruchu drogowym narzuca innym uczestnikom ruchu zachowanie szczególnej ostrożności w stosunku do pojazdów nauki jazdy. Kursanci są osobami, które oprócz nabywania wiedzy z zakresu przepisów ruchu drogowego muszą również opanować pewne zachowania z zakresu podzielności uwagi, szybkości reakcji, szanowania innych uczestników ruchu. Często są to osoby, które dopiero w trakcie kursu przełamują bariery psychologiczne znacznie utrudniające proces szkolenia. Ułatwić może im to tolerancja, szacunek i kultura ze strony uczestników ruchu drogowego - w tym przede wszystkim dobry przykład płynący od kierowców zawodowych.

Tab. 3. Wybrane wypowiedzi kierowców zawodowych o szkoleniach

\begin{tabular}{|c|c|}
\hline Badani kierowcy & Wypowiedzi kierowców o szkoleniach \\
\hline $\begin{array}{l}\text { Kierowca } \\
\text { w wieku } 35 \text { lat; } \\
11 \text { lat pracy } \\
\text { w firmie transpor- } \\
\text { towej świadczącej } \\
\text { usługi lokalne }\end{array}$ & $\begin{array}{l}\text { Szkolenia obowiązkowe nie wpływają znacząco na poprawę bezpieczeństwa } \\
\text { ruchu drogowego i są dodatkowym zobowiązaniem finansowym. Każdy } \\
\text { kierowca powinien doskonalić swoje umiejtności, gdyż przez } 11 \text { lat pracy } \\
\text { zauważyłem, że bardzo szybko można popaść w rutynę. W związku z tym } \\
\text { powinny być organizowane szkolenia - ale nie na zasadzie wykładów i zajęć } \\
\text { teoretycznych, lecz czysto praktyczne - doskonalące technikę jazdy }\end{array}$ \\
\hline $\begin{array}{l}\text { Kierowca } \\
\text { w wieku } 24 \text { lat; } \\
\text { roczny staż pracy } \\
\text { w firmie wykonu- } \\
\text { jącej przewozy } \\
\text { międzynarodowe }\end{array}$ & $\begin{array}{l}\text { Kwalifikacja wstępna, okresowa to bardzo dobry pomysł, gdyż jest zbyt duża } \\
\text { liczba wypadków z udziałem kierowców, co daje dużo do myślenia. W szkole } \\
\text { zawodowej przez pół roku miałem przedmiot - przepisy ruchu drogowego. } \\
\text { Oprócz tego uczestniczyłem w zajęciach teoretycznych w trakcie kursu nauki } \\
\text { jazdy i uważam, że takiej wiedzy nigdy nie jest za wiele. Korzystam z wszelkich } \\
\text { szkoleń organizowanych przez mojego pracodawcę. Przewozy międzynarodowe } \\
\text { to ogromna odpowiedzialność. Trzeba mieć wiedzę z zakresu techniki jazdy, } \\
\text { ekologii - ochrony środowiska, mechaniki, przepisów ruchu drogowego, } \\
\text { zabezpieczania ładunków. To wszystko jest poruszane w trakcie szkoleń } \\
\text { kwalifikacyjnych. Myślę, że w dzisiejszych czasach trzeba się ciągle dokształcać } \\
\text { zwłaszcza w tak mobilnym zawodzie, jakim jest zawód kierowcy }\end{array}$ \\
\hline
\end{tabular}

${ }_{5}^{5}$ Sondaż wśród kierowców przeprowadzono na potrzeby dyplomowej pracy inżynierskiej w marcu 2010. 


\begin{tabular}{|c|c|}
\hline Badani kierowcy & Wypowiedzi kierowców o szkoleniach \\
\hline $\begin{array}{l}\text { Kierowca } \\
\text { w wieku } 63 \text { lat; } \\
\text { kierowca } \\
\text { zawodowy, } \\
\text { od } 30 \text { lat w firmie } \\
\text { wykonującej } \\
\text { przewozy na } \\
\text { terenie kraju }\end{array}$ & $\begin{array}{l}\text { Szkolenia obowiązkowe to porażka ustawodawcy. Każdy kierowca zawodowy } \\
\text { ma swoją technikę jazdy i nie jest łatwo pozbyć się nawyków na rzecz zagadnień } \\
\text { poruszanych na szkoleniach. Uczestniczyłem w szkoleniu dotyczącym ekonomi- } \\
\text { ki jazdy, ale do dziś nie stosuję się do omawianych tam wskazówek. Nie jestem } \\
\text { w stanie operować biegami i pedałem sprzęgła inaczej niż przez ostatnie } 30 \text { lat, } \\
\text { tak aby pojazd spalał pół litra paliwa mniej. Młodzi ludzie - owszem - powinni } \\
\text { się kształcić, ale kierowcy z takim stażem jak mój mają już duże doświadczenie. } \\
\text { Szkolenia powinny być organizowane tylko dla chętnych, rzeczywiście chcących } \\
\text { podnieść swoje kompetencje }\end{array}$ \\
\hline
\end{tabular}

Źródło: Burzyński, 2010, s. 76-78.

\section{Bezpieczeństwo ruchu drogowego jako podstawa programów szkoleń}

Badania stanu bezpieczeństwa w ruchu drogowym wskazują, że 97\% zdarzeń zachodzi z przyczyn subiektywnych, czyli zależnych od człowieka. Wśród nich powyżej 80\% stanowią kolizje i wypadki zawinione przez kierującego (ryc. 3). Pomijając takie przyczyny, jak nietrzeźwość kierowcy (12\% wypadków), zaśnięcie lub zasłabnięcie za kierownicą (2\%), większość zdarzeń drogowych spowodowana jest niekompetencją kierowców i nieświadomie popełnianymi przez nich błędami. Przytaczane w statystykach policyjnych charakterystyki wypadków przedstawiają jedynie takie zachowanie kierowcy, które bezpośrednio doprowadziło do wypadku, pomijając realne przyczyny takiego zachowania. Na przykład: niedostosowanie prędkości do warunków ruchu, określane także jako jazda z nadmierną prędkością, może być skutkiem brawury kierującego, błędu w ocenie sytuacji lub braku pewnych umiejętności w zakresie techniki jazdy. Nieudzielanie pierwszeństwa przejazdu może być natomiast wynikiem braku odpowiedniej wiedzy w zakresie przepisów ruchu drogowego lub też świadomego ich przekraczania, niewłaściwej oceny sytuacji drogowej - przeświadczenia, że jeszcze zdąży się przejechać - lub zwyczajnie niewłaściwie wykonanego manewru. Niezachowanie bezpiecznej odległości między pojazdami może być równie dobrze skutkiem braku doświadczenia kierowcy, który nie potrafi odpowiednio ocenić przebiegu drogi hamowania w istniejących warunkach drogowych, ale również braku umiejętności efektywnego hamowania. Analizując w podobny sposób kolejno następujące po sobie pozycje policyjnych raportów, zauważa się, że rzeczywiste przyczyny zdarzeń drogowych zawinionych przez kierowców stanowią kolejno: zachowania, które wynikają z niewłaściwych postaw (brawura, bezmyślność), zachowania, które wynikają z braku doświadczenia, wiedzy i umiejętności niezbędnych w określonej sytuacji.

Ryc. 3. Podstawowe czynniki ryzyka wystąpienia zdarzeń niepożądanych

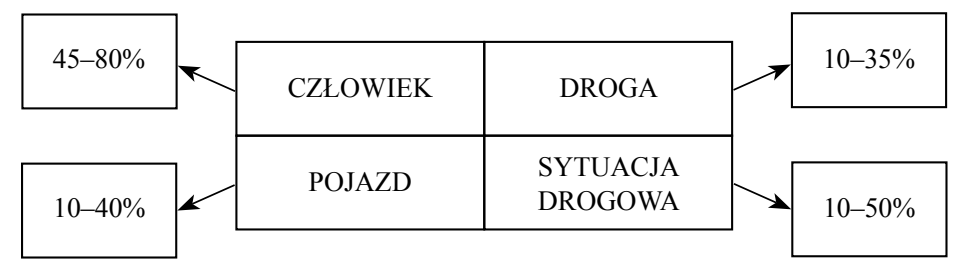

Źródło: opracowanie własne autora na podstawie materiałów z „Fleet Conference”, Ożarów Mazowiecki 23.03.2010. 
Niezależnie od tego, czy kierowcy poruszają się pojazdami własnymi, czy służbowymi, czy ich staż w prowadzeniu pojazdu jest krótki, czy też długi, czy są kierowcami zawodowymi, czy nie, popełniają z reguły takie same błędy podstawowe. Są to: błędy w ocenie sytuacji: nieuwzględnienie zmieniających się warunków drogowych, nieuwzględnienie zachowań innych uczestników ruchu, nieumiejętność wczesnego przewidywania zagrożeń, błędy w podejmowaniu decyzji: podejmowanie nieodpowiednich działań, nieumiejętność powstrzymania się od działania, błędy w technice jazdy: nieefektywne hamowanie, nieskuteczne ruszanie z miejsca, nieodpowiednie operowanie kierownicą. Na drogach będzie niewątpliwie bezpieczniej, jeżeli podejmie się systematyczne starania w kierunku eliminacji tych zachowań. Ogromną rolę w tych działaniach mogą spełnić szkolenia kierowców, które mają za zadanie podnosić świadomość zagrożeń oraz doskonalić umiejętności i których brak bezpośrednio przyczynia się do powstawania kolizji i wypadków. Szkolenia przyniosą spodziewane efekty tylko i wyłącznie pod warunkiem, że będą przemyślanym i celowym procesem nauczania, który realizowany będzie przez instruktorów posiadających odpowiednie przygotowanie merytoryczne i pedagogiczne, w specjalnie przystosowanych ośrodkach doskonalenia techniki jazdy, wyposażonych w systemy bezpiecznej symulacji trudnych i niecodziennych sytuacji drogowych (np. płyty poślizgowe, kurtyny wodne) (Zielińska 2006).

Szkolenia kierowców zawodowych są również zasadniczym elementem prewencji w zarządzaniu bezpieczeństwem w firmie transportowej i stawia się je na pierwszym miejscu po polityce personalnej przedsiębiorstwa, przed takimi czynnikami, jak: kultura organizacji, dobór samochodu do floty, zakładowy kodeks kierowców, zarządzanie szkodowością, określenie odpowiedzialności, logistyka i inne czynniki (ryc. 4).

Ryc. 4. Prewencja w zarządzaniu bezpieczeństwem floty

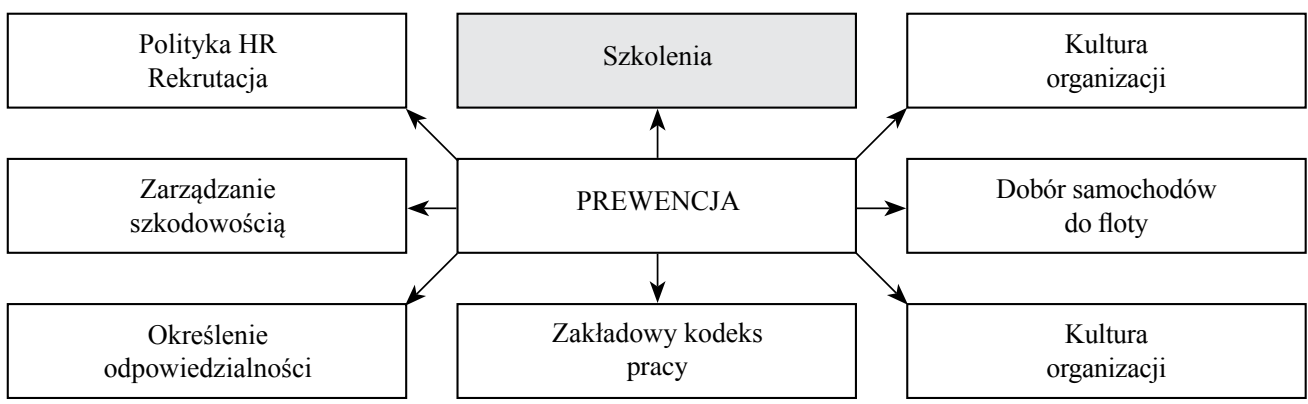

Źródło: opracowanie własne autora na podstawie materiałów z Fleet Conference, Ożarów Mazowiecki 2010.03.23.

\section{Cechy kierowcy zawodowego a przedsiębiorczość}

Od osoby kierującej pojazdem samochodowym wymaga się między innymi opanowania, spostrzegawczości, koncentracji, podzielności uwagi, szybkości reakcji, celowości decyzji, zasobu wiedzy o ruchu drogowym, umiejętności i doświadczenia w kierowaniu pojazdem, umiejętności dostosowania się, tolerancji i poszanowania dla innych uczestników drogi oraz wytrzymałości fizycznej i psychicznej.

Kierowca powinien posiadać szczególne predyspozycje psychofizyczne, a jego bezpieczne funkcjonowanie zależy od określonych cech i sprawności, do których należą: sprawność procesów intelektualnych i poznawczych, sprawność psychomotoryczna i psychofizyczna oraz cechy temperamentu i osobowości. Sprawność procesów intelektualnych i poznawczych 
umożliwia kierowcy trafną ocenę sytuacji na drodze i podejmowanie właściwych decyzji, sprawność psychomotoryczna i psychofizyczna umożliwia sprawne wykonanie podjętych decyzji, zaś cechy temperamentu i osobowości decydują między innymi o trafności samooceny, odpowiedzialności w działaniu, samokontroli emocjonalnej, dojrzałości społecznej, stylu działania (Łuczak, Najmiec 2009). Nasilenie tych cech i sprawności może zmieniać się w zależności od stanowiska pracy - samochód ciężarowy, autobus, samochód osobowy i inne.

Najważniejsze cechy osobowości kierowcy zawodowego to wytrzymałość na długotrwały wysiłek, odporność emocjonalna, samokontrola, samodzielność, umiejętność podejmowania szybkich i trafnych decyzji, umiejętność pracy w szybkim tempie i łatwość przerzucania się z jednej czynności na drugą, umiejętność pracy w warunkach izolacji społecznej i warunkach monotonnych, umiejętność postępowania i nawiązywania kontaktu z ludźmi oraz dokładność. Kierowcę zawodowego powinny także cechować następujące zdolności: zdolność koncentracji uwagi, podzielność uwagi, wyobraźnia przestrzenna, uzdolnienie techniczne, dobra pamięć, rozumowanie logiczne, wyobraźnia i myślenie twórcze. Od kierowcy wymaga się również zdolności i zainteresowań technicznych, a w szczególności znajomości budowy samochodu oraz umiejętności diagnozowania i obsługi jego zespołów. Wymienione cechy i sprawności kierowców zawodowych związane są głównie z efektywnym procesem kierowania pojazdem, przy czym należy pamiętać i o tym, że kierowcy są też pracownikami, których praca ma istotny wpływ na efektywne funkcjonowanie całego przedsiębiorstwa. Zatem do pożądanych cech ich osobowości należy zaliczyć również przedsiębiorczość, zwłaszcza, że w ostatnich czasach w obszarze funkcji personalnej przedsiębiorstw, w tym transportowych, uwidoczniły się zmiany polegające na przesunięciu punktu ciężkości z czynności administracyjnych na poszukiwanie nowych źródeł osiągania przewagi konkurencyjnej, opartych na cechach i zachowaniach przedsiębiorczych pracowników (ryc. 5). Ich wiedza, umiejętności oraz zdolności w tym zakresie zaczęły być traktowane jako czynnik różnicujący efektywnie i nieefektywnie działające firmy. Oznacza to, że w ewolucji funkcji personalnej przedsiębiorstw nastąpił zwrot w kierunku traktowania pracowników jako właścicieli niepowtarzalnych kompetencji, mających istotną wartość dla przedsiębiorstwa. W efekcie przedsiębiorczość pracowników jest dzisiaj główną siłą kreatywną każdej firmy, wpisaną na trwałe w jej system zarządzania oraz kulturę organizacyjną (Drozdowski 2006).

Ryc. 5. Wybrane cechy przedsiębiorczego pracownika

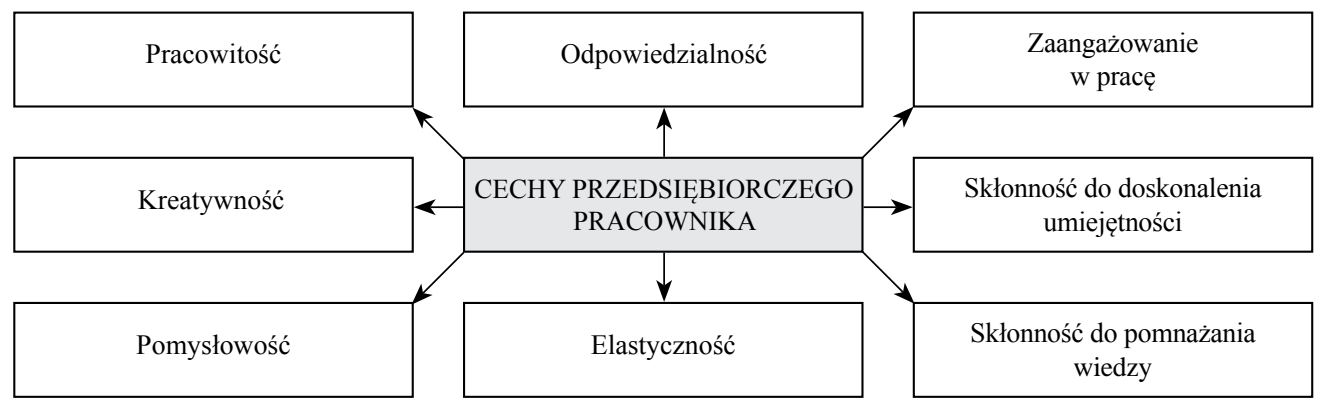

Źródło: opracowanie własne. 
W rozważaniach nad przedsiębiorczością kierowców zawodowych warto też wrócić do spostrzeżeń prakseologów, którzy bezpośrednio nie używali terminu przedsiębiorczość, lecz dostrzegali cechy człowieka przedsiębiorczego uzewnętrzniające się w jego działaniu (Kotarbiński 1975; Pszczołowski 1978). Zatem kierowcy zawodowi oprócz wymaganych standardowych cech związanych z kierowaniem pojazdem samochodowym, powinni być kreatywni, pracowici, opanowani, pomysłowi, zaangażowani w swoją pracę, odpowiedzialni, elastyczni, winni też stale pomnażać swoją wiedzę i doskonalić swoje umiejętności, gdyż to właśnie oni stanowią trzon personelu przedsiębiorstwa transportowego i mają bezpośredni wpływ na obniżanie kosztów eksploatacyjnych pojazdów i podnoszenie bezpieczeństwa ruchu drogowego.

Kierowcy zawodowi, pokonujący dziesiątki tysięcy kilometrów rocznie, w większości bardzo doświadczeni, mogą również popełniać elementarne błędy zwiększające zagrożenie w ruchu drogowym, a także skutkujące większymi kosztami eksploatacyjnymi samochodu i tym samym wyższymi kosztami prowadzenia przedsiębiorstwa transportowego. Błędy te mogą być między innymi skutkiem złej nauki jazdy w przeszłości lub brakiem okazji do poddania się fachowej ocenie i doskonalenia techniki jazdy. Szkolenia dla kierowców zawodowych odgrywają znaczącą rolę w kształtowaniu ich umiejętności, przyczyniają się do wzrostu bezpieczeństwa ruchu drogowego, poziomu wiedzy na temat racjonalnej eksploatacji pojazdów, a także do jej praktycznego stosowania. W związku z rosnącym znaczeniem transportu drogowego oferta szkoleń proponowanych kierowcom jest coraz bogatsza. Według kryterium obowiązku uczestnictwa przez kierowców w szkoleniach, można je podzielić na obligatoryjne i nieobligatoryjne. Zarówno szkolenia obligatoryjne, jak i nieobligatoryjne umożliwiają praktyczne sprawdzenie wiedzy teoretycznej. Jednym z głównych elementów programów wszelkich szkoleń dla kierowców jest bezpieczeństwo ruchu drogowego i zwiększenie świadomości kierowców w zakresie racjonalnej eksploatacji pojazdu. Kierowcy w trakcie takich szkoleń poznają zasady ekonomicznej jazdy, zasady racjonalnego prowadzenia pojazdu, poziom własnej agresji czy też techniki jazdy defensywnej. Wszystkie te elementy sprzyjają doskonaleniu posiadanych umiejętności oraz nabywaniu nowych. Udowodniono, że odpowiednia technika jazdy może pozytywnie wpływać na zużycie paliwa i na pozostałe składniki eksploatacji pojazdu. Przepisy regulujące zmiany w systemie szkolenia kierowców ulegają ciągłym zmianom. Planowane rozwiązania prawne mają na celu systematyczne poprawienie bezpieczeństwa na drogach oraz podnoszenie kwalifikacji kierowców, efektem tych działań ma być całkowita eliminacja do 2050 roku śmiertelnych wypadków oraz znaczne obniżenie zużycia paliw pierwotnych (Biała Księga). Aby zrealizować te ambitne cele, niezbędna jest, oprócz działań kolejnych parlamentów i rządów, przedsiębiorczość pracowników firm transportowych, a w szczególności ich kierowców, przejawiająca się skłonnością do pomnażania wiedzy i doskonalenia swych umiejętności. 


\section{Literatura}

1. Autobusy komunikacji miejskiej Ipswich z Fleet Managerem, http://drabpol.pl/pl/STRONAG\%C5\%81\%C3\%93WNA/tabid/38/Default.aspx (dostęp: 11.08.2011).

2. Bezpiecznie znaczy oszczędnie, 200902 20, http://www.flota.com.pl/cms/index.php/27735/bezpiecznie_znaczy_oszczednie.html (dostęp: 25.07.2011).

3. Biała Księga. Plan utworzenia jednolitego europejskiego obszaru transportu-dązenie do osiagnięcia konkurencyjnego i zasobooszczędnego systemu transportu, Komisja Europejska, Bruksela, dnia 28.03.2011.

4. Bratnicki M., Strużyna J., red., 2001, Przedsiębiorczość i kapitat intelektualny, Wydawnictwo Akademii Ekonomicznej w Katowicach, Katowice.

5. Bratnicki M., 2002, Przedsiębiorczość i przedsiębiorcy współczesnych organizacji, Wydawnictwo Akademii Ekonomicznej w Katowicach, Katowice.

6. Bratnicki M., ed., 2003, Organizational entrepreneurship: conceptual advances and some empirical tests, Katowice.

7. Burzyński Sz., 2010, Kierunki zarządzania wiedza w przedsiębiorstwie transportowym na przykładzie szkoleń kierowców w Polsce, Akademia Humanistyczno-Ekonomiczna w Łodzi, inżynierska praca dyplomowa, promotor dr inż. Jerzy Janczewski, Łódź.

8. Cooke P.N.C., 2004, Zarządzanie ryzykiem i bezpieczeństwem floty, IPM sp. z o.o., Wrocław.

9. Cooke P.N.C., 2005, Zarządzanie flota samochodowa Strategie, IPM sp. z o.o., Wrocław.

10. Czy zabraknie kierowców zawodowych?, http://www.log24.pl/artykuly/czy-zabraknie-kierowcow-zawodowych,605 (dostęp: 6.10.2011).

11. Doskonalenie techniki jazdy na symulatorze jazdy w WSCiL, http://truckfocus.pl/szkolenia/5470/ doskonalenie-techniki-jazdy-na-symulatorze-jazdy-w-wscil?n30 (dostęp: 16.08.2011).

12. Drozdowski G., 2006, Przedsiębiorczość w świetle wspótczesnych koncepcji zarządzania kapitałem ludzkim, „Studia Lubuskie” nr 2/2006, PWSZ Sulechów, s. 223-229.

13. Drucker P.F., 1992, Innowacje i przedsiębiorczość. Praktyka i zasady, PWE, Warszawa.

14. Drucker P.F., 2002, Myśli przewodnie Druckera, MT Biznes, Warszawa.

15. Dyrektywa 2003/59/WE Parlamentu Europejskiego i Rady z dnia 15 lipca 2003 r. w sprawie wstęnej kwalifikacji i okresowego szkolenia kierowców niektórych pojazdów drogowych do przewozu rzeczy lub osób, Dz.U UE, L 226/4 (dostęp: 10.09.2003).

16. ERIC przeszkoli kierowców, http://moto.onet.pl/1566200,1,eric-przeszkoli-kierowcow,artykul.htm1?node=2 (dostęp: 27.07.2011).

17. Fleet Conference, Ożarów Mazowiecki 23.03.2010, materiały niepublikowane.

18. Fleet \&Business Day 2010, Warszawa 02.12.2010, materiały niepublikowane.

19. Kirzner I., 2003, Competition and Entrepreneurship, University of Chicago Press, Chicago 1973 [w:] M. Łuczak (red.), Przedsiębiorczość w zarządzaniu firma, Wyższa Szkoła Ekonomiczna w Warszawie, Warszawa.

20. Kotarbiński T., 1975, Traktat o dobrej robocie, wyd. 6, Zakład Narodowy im. Ossolińskich, Wrocław.

21. Łuczak A., Najmiec A., 2009, Badania sprawności psychofizycznej kierowców wypadkowych i bezwypadkowych $w$ aspekcie prewencji wypadkowej $i$ zwiększania kultury bezpieczeństwa $w$ transporcie drogowym, Praca naukowo-badawcza z zakresu prewencji wypadkowej, CIOP, Warszawa.

22. Mercedes szkoli kierowców, http://infobus.pl/text.php?from=mail\&id=31740 (dostęp 26.07.2011).

23. Mitraszewska I., Kaminska E., 2007, Rynek pracy w Polsce ze szczególnym uwzględnieniem rynku pracy kierowców zawodowych, „Biuletyn Instytutu Transportu Samochodowego”, zeszyt 2(20), s. 4-16.

24. Nie wszyscy wiedza jak oszczędniej jeździć, http://www.wnp.pl/wiadomosci/152712.html, (dostęp: 11.10.2011).

25. Pszczołowski T., 1978, Mała encyklopedia prakseologii i teorii organizacji, Zakład Narodowy im. Ossolińskich, Warszawa. 
26. Scania Driver Support, http://www.scania.pl/trucks/safety-driver-support/driver-support-systems/ scania-driver-support/ (dostęp: 26.07.2011).

27. Sexton D., Bowman-Upton N., 1991, Entrepreneurship, Macmillan, New York.

28. Symela K., Rozwój doskonalenia zawodowego w innowacyjnej gospodarce, Instytut Technologii i Eksploatacji, Państwowy Instytut w Radomiu, http://innowacyjneprogramy.pl/publikacje/Innowa art_Symela.pdf (dostęp: 30.09.2011).

29. Systemy Scanii monitorujace wydajność kierowcy i pojazdu, http://truckfocus.pl/nowosci/5550/ systemy-scanii-monitorujace-wydajnosc-kierowcy-i-pojazdu?n35= (dostęp: 20.09.2011).

30. Uniwersalny model kompetencyjny, 2011, Fundacja Obserwatorium Zarządzania, Warszawa.

31. Ustawa z dnia 6 września 2001 r. o transporcie drogowym ze zmianami, które weszły w życie do dnia 1 września 2011.

32. Ustawa z dnia 20 czerwca 1997 r. Prawo o ruchu drogowym ze zmianami, które weszły w życie do dnia 6 maja 2011.

33. Zielińska A., 2006, Rok 2005 na polskich drogach. Analiza danych o wypadkach drogowych, „Kwartalnik BRD”, nr 1.

\section{Improvement trainings for professional drivers versus entrepreneurship}

The aim of the article is to discuss problems and assumed results of training of the professional drivers in Poland. It presents the participants of the training system and it describes the training process starting from a candidate for a course and finishing with acquiring the driving license of the professional driver. Additionally, it indicates a role and influence of the personnel of the transportation companies over the transportation costs. It also discusses significance of such trainings and entrepreneurship from the point of view traffic road safety and reasonable cars exploitation. 